GPJI 3(2)(2019) Gelanggang Pendidikan Jasmani Indonesia

\title{
PENGARUH PEMBELAJARAN METODE DRILL TERHADAP PENINGKKATAN HASIL BELAJAR LEMPAR BOLA SOFTBALL KELAS 7 SMP NEGERI 1 KOTA MALANG
}

\begin{abstract}
Abimantrana Astari Pradana ${ }^{1 \bowtie,}{ }^{2}$
Universitas Negeri Malang

abimantrana.ap@gmail.com

\section{Info Artikel}

Sejarah Artikel:

Diterima: September-2019

Disetujui: Desember-2019

Dipublikasikan : Desember-2019

Kata Kunci:

pembelajaran, metode drill, hasil

belajar, lempar, softball

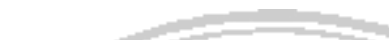

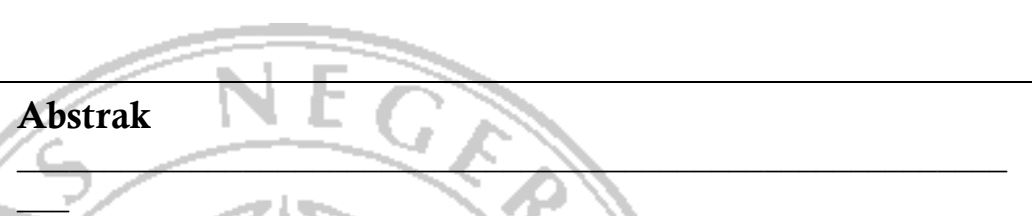

Tujuan penelitian ini untuk mengetahui peningkatan hasil belajar lempar bola softball akibat pembelajaran metode drill dinamis dan statis. Hasil analisis varian satu jalur dan LSD $\alpha 0,05\left(F_{\text {hitung }} 13,0949>F_{\text {tabel } \alpha 0,05} 4,1708\right.$ dan $\overline{\boldsymbol{X}}_{\mathbf{1}}$ vs $\left.\overline{\boldsymbol{X}}_{\mathbf{2}} 1,60>\mathrm{LSD}_{\alpha 0,05} 0,01\right)$ ada perbedaan pengaruh pembelajaran metode drill dinamis dan statis terhadap peningkatan hasil belajar lempar bola softball. Pembelajaran drill dinamis lebih baik terhadap peningkatan hasil belajar lempar bola softball dibandingkan drill statis.

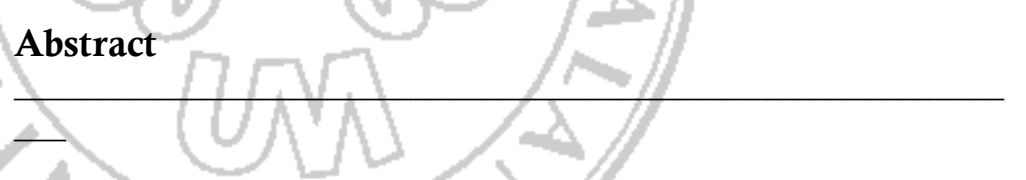

The Purpose of this research is to know the effect of learning method of dynamic drill and static drill to increase learning result of throwing in softball. The result of one way anova analysis and LSD $\alpha 0,05\left(F_{\text {count }} 13,0949>F_{\text {table } \alpha 0,05} 4,1708\right.$ and $\bar{X}_{1}$ vs $\bar{X}_{2} 1,60$ $\left.>L S D_{\alpha 0,05} 0,01\right)$ mean there is difference of influence effect of learning drill and command method to increase learning result throwing in softball. Learning dynamic drill method is better than static drill method to increase result softball throwing.
\end{abstract}

(C) 2019 Universitas Negeri Malang

\footnotetext{
Alamat korespondensi:

E-mail: abimantrana.ap@gmail.com
}

ISSN: 2614-8293 (Online)

\section{PENDAHULUAN}

Saat ini kemampuan siswa melakukan teknik-teknik dalam mata pelajaran pendidikan jasmani cukup rendah. Hal tersebut dikarenakan siswa kurang bersemangat dan kurang fokus dalam melakukan kegiatan pembelajaran. Faktor lain yang menyebabkan kemampuan siswa rendah adalah para siswa mudah merasa bosan dengan pembelajaran yang dilakukan oleh guru. Variasi metode 
pembelajaran dibutuhkan dalam kegiatan pembelajaran. Variasi metode dibutuhkan untuk menghilangkan rasa bosan siswa dalam melakukan kegiatan pembelajaran. Selain itu variasi metode dilakukan untuk meningkatkan kemampuan siswa dalam pengusaan teknik-teknik yang diajarkan saat pembelajaran.

Rendahnya kemampuan teknik dasar siswa juga terjadi pada pembelajaraan softball. Salah satu teknik dasar dalam softball yang harus dikuasai adalah melempar. Menurut Christina dan Advendi (2011:15) yang menyatakan bahwa terdapat beberapa teknik dasar yang harus dikuasai oleh seorang pemain softball, yaitu teknik melempar, menangkap, memukul bola, lari mengelilingi lapangan (base running), dan sliding. Hal tersebut dikarenakan, inti dari permainan softball adalah lempar dan tangkap. Hampir seluruh permainan didominasi oleh lemparan bola baik dari jarak yang cukup dekat hingga jarak yang jauh.

Di dalam proses belajar-mengajar, guru harus memiliki strategi agar siswa dapat belajar secara efektif dan efisien, mengena pada tujuan yang diharapkan._Menurut Hamid (2012:216), "metode latihan atau drill merupakan metode yang digunakan guru untuk mengajar dalam upaya menanamkan berbagai kebiasaan atau keterampilan tertentu kepada para siswa". Hal tersebut sebagai sarana untuk memperoleh suatu ketangkasan, ketepatan, kesempatan, dan keterampilan. Dengan mengulangi gerakan atau kegiatan yang dilakukan, maka seseorang akan dapat membentuk suatu kebiasaan yang akan direkam oleh otak.

Menurut Khanifatul (2013:14) menjelaskan " pembelajaran adalah usaha sadar yang dilakukan oleh guru atau peserta didik untuk membuat siswa atau peserta didik belajar (mengubah tingkah laku untuk mendapatkan kemampuan baru) yang berisi suatu sistem atau rancangan untuk mencapai suatu tujuan". Hubungannya dengan beberapa hal yang tidak bisa ditinggalkan dalam mencapai tujuan pembelajaran adalah cara pengajar atau guru dalam mengkoordinasi bahan ajarnya, mengkoordinasi murid, dan bagaimana menata interaksi antara sumber belajar yang ada supaya dapat berfungsi secara optimal.

Ciri utama dari kegiatan pembelajaran adalah adanya interaksi yang terjadi antara siswa dengan lingkungan belajarnya, baik itu dengan guru, teman-temannya, media pembelajaran, dan atau sumber-sumber belajar yang lain, yang berkaitan dengan komponen-komponen pembelajaran itu sendiri. Menurut Riyana (2010:3) yang menyatakan bahwa "di dalam pembelajaran akan terdapat komponen-komponen sebagai berikut; tujuan, materi/bahan ajar, metode dan media, evaluasi, anak didik/siswa, dan pendidik/guru".

Belajar dan proses pembelajaran erat kaitannya dengan proses kearah perubahan sebagai hasil belajar. Banyak kelompok teori yang memberikan pandangan khusus tentang hasil belajar. Salah satunya teori belajar Gagne yang merupakan perpaduan seimbang antara behaviorisme dan kognitivisme yang berpangkal pada teori pengolahan informasi. Gagne (dalam Ainurrahman, 2013:46-47) menyimpulkan ada 5 macam hasil belajar, (1) keterampilan intelektual, (2) strategi kognitif, (3) informasi verbal, (4) keterampilan motorik, (5) sikap. Dapat disimpulkan bahwa pembelajaran merupakan proses kegiatan atau interaksi yang dilakukan anatar guru dan siswa maupun interaksi siswa dengan sumber belajar lainnya untuk mencapai suatu tujuan.

Beberapa penelitian sehubungan dengan metode drill pernah dilakukan sebelumnya, di antaranya dengan judul Upaya Meningkatkan Keterampilan Smash Bolavoli Menggunakan Metode Drill Bervariasi untuk Pembelajaran Siswa Kelas Olahraga SMP Negeri 1 Batu oleh Pradanang Arif Wibowo (2012), penelitian yang dilakukan oleh Miqdad Yosi Nizhom Fahmi (2018) dengan judul Pengaruh Pembelajaran Variasi Dribble Lurus dan Dribble Zig-zag Menggunakan Modifikasi Bola Plastik terhadap Peningkatan Hasil Belajar Keterampilan Dribble Sepakbola Siswa Kelas XI SMAN 5 Malang, dan penelitian yang dilakukan oleh Tri Sakti Oktaviani (2018) dengan judul Pengaruh Pembelajaran Metode Drill dan Komando terhadap Peningkatan Hasil Belajar Dribble Bolabasket Kelas XI SMAN 5 Malang. Berdasarkan beberapa penelitian tersebut, dapat disimpulkan bahwa metode drill adalah proses yang sistematis dari berlatih yang dilakukan secara berulang-ulang sehingga memeroleh suatu keterampilan tertentu. Metode drill dengan variasi yang diberikan dapat meningkatkan keterampilan tertentu.

Dapat disimpulkan bahwa metode drill atau latihan adalah metode cara mengajar dengan melakukan kegiatan yang berbasis menanamkan kebiasaan-kebiasaan tertentu yang bertujuan agar siswa memiliki ketangkasan dari materi yang diberikan oleh guru. Dalam penelitian ini peneliti akan menggunakan metode drill sebagai metode yang diterapkan kepada objek penelitian agar mampu menguasai teknik lempar dalam olahraga softball. Metode drill yang digunakan dalm penelitian ini dibedakan menjadi dua macam yakni, drill dinamis dan drill statis. Drill dinamis dimaksudkan dengan 
melakukan gerakan melempar bola softball dengan menggunakan awalan berlari atau berjalan, sedangkan drill statis dalam penelitian ini dimaksudkan dengan melakukan gerakan lempar bola softball tanpa menggunakan awalan.

Hasil tes awal observasi berupa tes lempar bola softball yang dilakukan oleh peneliti, ditemukan 3 orang $(8,82 \%)$ terdapat pada kategori baik sekali, 5 orang $(14,71 \%)$ terdapat pada kategori baik, 11 orang $(32,35 \%)$ terdapat pada kategori cukup, 5 orang $(8,82 \%)$ terdapat pada kategori kurang, dan 10 orang $(29,41 \%)$ terdapat pada kategori sangat kurang.

Berdasarkan penjelasan dan fakta mengenai pembelajaran lempar bola softball yang telah disebutkan , maka telah dilakukan penelitiandengan judul "Pengaruh Pembelajaran Metode Drill Terhadap Peningkatan Hasil Belajar Lempar Bola Softball Kelas 7 SMP Negeri 1 Kota Malang ". Secara khusus, penelitian memiliki tujuan untuk mengetahui perbedaan pengaruh pembelajaran antara metode drill dinamis dan statis yang paling efektif terhadap peningkatan hasil belajar lempar bola softball kelas 7 SMP Negeri 1 Kota Malang.

\section{METODE}

Penelitian ini menggunakan rancangan penelitian eksperimen bentuk "desain randomized control group pretest-posttest". Dilihat dari masalah yang diteliti, jenis penelitian ini termasuk dalam penelitian eksperimen semu. Variabel yang diteliti berupa, (1) variabel terikat yaitu hasil belajar lempar jauh bola softball, (2) variabel bebas yaitu, (a) metode drill dinamis dan (b) metode drill statis.

Populasi dalam penelitian ini adalah siswa kelas 7B SMP Negeri 1 Kota Malang yang mendapat pembelajaran softball berjumlah 32 siswa. Teknik sampel yang dipilih adalah purposive sistematic random sampling. Sesuai dengan rancangan yang disusun dalam penelitian ini, maka dalam penelitian ini peneliti membagi kelompok menjadi dua kelompok dengan menggunakan teknik ordinal pairing matching (Kusumawati, 2015:90) yaitu kelompok eksperimen dan kelompok kontrol (sebagai pembanding).

Instrumen yang digunakan dalam penelitian ini berupa instrumen tes dan non-tes. Tes yang dilakukan dalam penelitian ini berupa tes lempar bola dengan jarak sejauh-jauhnya dari garis batas lempar, dan instrumen non-tes dalam penelitian ini berupa lembar pedoman observasi yang digunakan untuk mengamati pelaksanaan tes lempar jauh bola softball dan pelaksanaan pembelajaran.

Teknik pengumpulan data menggunakan (1) teknik pengukuran bentuk tes berupa tes lempar bola softball, (2) teknik eksperimen dengan memberikan treatment berupa pembelajaran, dan (3) teknik observasi untuk mengamati tes keterampilan dan pembelajaran teknik dasar melempar. Tahapan pengumpulan data dimulai dengan tahap persiapan, (a) menentukan subyek penelitian, (b) mengajukan surat ijin penelitian, (c) menyusun RPP menggunakan metode drill dinamis dan drill dinamis, (d) menyusun petunjuk pelaksanaan tes, dan (e) menyiapkan sarana prasarana. Tahap pelaksanaan, penulis melakukan kegiatan, (a) memberi penjelasan mengenai instrumen tes lempar bola softball, (b) melakukan tes awal (pretest) berupa tes lempar bola softball, (c) pelaksanaan pemberian perlakuan berupa metode drill dinamis dan drill dinamis selama 6 minggu yang dalam setiap minggunya terdapat 2 kali pertemuan, (d) melakukan tes akhir (posttest) berupa tes lempar bola softball, (e) mengumpulkan hasil tes yang telah dilakukan, dan (f) menganalisis data yang telah diperoleh.

Berdasarkan tujuan penelitian dan dengan pertimbangan jenis data berupa data rasio, maka data yang terkumpul dianalisis menggunakan uji-t berpasangan dan analisis varian satu jalur (one way anova). Analisis varian satu jalur membutuhkan persyaratan yang harus dipenuhi, yaitu uji normalitas data menggunakan teknik Lilliefors (Djudin, 2013:7) dan uji homogenitas varian dalam populasi dilakukan dengan teknik uji Fmax (Sudaryono dan Asep, 2012:211). Jika hasil analisis varian satu jalur (one way anova) $\mathrm{F}_{\text {hitung }}>\mathrm{F}_{\text {tabel }}=0,05$, dilakukan uji lanjut menggunakan uji Leat Significance Difference (LSD). Prosedur analisis data dilakukan secara manual dengan menggunakan bantuan kalkulator Casio FX 3900 PV. Pengujian hipotesis menggunakan taraf signifikasi $\alpha=0,05$.

\section{HASIL}

Hasil data tes keterampilan lempar bola softball untuk analisis adalah skor awal (pretest) dan skor akhir (posttest) keterampilan lempar bola softball peserta didik kelas 7B SMP Negeri 1 Malang. Deskripsi data hasil tes keterampilan lempar bola softball terdapat pada tabel 1. 
Tabel 1. Data Hasil

\begin{tabular}{llcc}
\hline Data Hasil Belajar & & Tes Awal (m) & Tes Akhir (m) \\
\hline & N & 17 & 17 \\
Kelompok Drill Dinamis & Mean & 16,6125 & 21,3188 \\
& SD & 2,9019 & 3,20 \\
& Max & 21,5 & 27,3 \\
& Min & 11,5 & 15,5 \\
\hline \multirow{3}{*}{ Kelompok Drill Statis } & N & 17 & 17 \\
& Mean & 16,6063 & 19,7125 \\
& SD & 2,7709 & 3,1874 \\
& Max & 20,8 & 25,4 \\
& Min & 12,3 & 15,1 \\
\hline
\end{tabular}

Keterangan:

$\mathrm{N} \quad$ : Jumlah sampel

mean : Rata-rata skor tes keterampilan lempar bola softball

SD : Standar deviasi (simpangan baku)

maks : Skor maksimum hasil tes lempar bola softball

min : Skor minimum hasil tes lempar bola softball

Berdasarkan hasil analisis uji normalitas menggunakan teknik liliefors, diperoleh untuk kelompok drill dinamis pada jarak lempar untuk tes awal yaitu $\mathrm{L}_{\text {hitung }} 0,0966<\mathrm{L}_{\text {tabel }} \alpha 0,050,2130$, pada saat pelaksanaan tes akhir diperoleh $\mathrm{L}_{\text {hitung }} 0,0645<\mathrm{L}_{\text {tabel }}$ \& 0,05 0,2130 . Berdasarkan hasil analisis uji normalitas menggunakan teknik liliefors, diperoleh untuk kelompok drill statis pada jarak lempar untuk tes awal yaitu $\mathrm{L}_{\text {hitung }} 0,1172<\mathrm{L}_{\text {tabel }} \alpha 0,050,2130$, pada saat pelaksanaan tes akhir diperoleh $\mathrm{L}_{\text {hitung }} 0,1496$ $<\mathrm{L}_{\text {tabel } \alpha 0,05} 0,2130$.

Berdasarkan hasil analisis data uji normalitas untuk seluruh kelompok menggunakan teknik liliefors pada waktu tes awal diperoleh hasil $L_{\text {hitung }} 0,0860$ dan $L_{\text {tabel }} 0,050,15662$, dan pada waktu tes akhir diperoleh hasil L Litung 0, 0972 dan $\mathrm{L}_{\text {tabel }} \alpha 0,050,15662$. Secara keseluruhan hasil analisis uji normalitas untuk populasi kelompok tes awal dan tes akhir $\mathrm{L}_{\text {hitung }}<\mathrm{L}_{\text {tabel }}$ 0,05, sehingga data menunjukkan berdistribusi normal dan analisis lanjutan dapat dilakukan.

Berdasarkan hasil analisis data uji homogenitas menggunakan Uji $\mathrm{F}$ yang telah dilaksanakan kelompok pembelajaran drill dinamis memperoleh hasil varian untuk $\mathrm{F}_{\text {hitung }} 1,2160<\mathrm{F}_{\text {tabel }} 0,054,6001$. Hasil analisis data uji homogenitas menggunakan Uji $F$ yang telah dilaksanakan kelompok pembelajaran drill statis memperoleh hasil varian untuk $\mathrm{F}_{\text {hitung }} 1,150<\mathrm{F}_{\text {tabel } \alpha 0,05} 4,6001$. Secara keseluruhan hasil analisis uji homogenitas pretest dan posttest untuk populasi kelompok pembelajaran metode drill dinamis dan drill statis menunjukkan varian populasi homogen, sehingga analisis lanjutan dapat dilakukan.

Hasil analisis uji-t berpasangan dengan taraf signifikansi $\alpha=0,05$ pada kelompok pembelajaran drill dinamis memperoleh $t_{\text {hitung }} 13,640>t_{\text {tabel } \alpha 0,05} 2,145$, pada kelompok drill statis memperoleh $t_{\text {hitung }}$ $11,234>t_{\text {tabel } \alpha 0,05} 2,145$. Hal tersebut menunjukkan bahwa adanya perbedaan antara sebelum dan sesudah pembelajaran menggunakan metode drill dinamis dan drill statis.

Hasil analisis varian satu jalur (Anova One way) memperoleh hasil $F_{\text {hitung }} 13,095>F_{\text {tabel } \alpha 0,05}$ 4,1708. Hal tersebut menunjukkan ada perbedaan pengaruh antara pembelajaran metode drill dinamis dan pembelajaran metode drill statis terhadap peningkatan hasil belajar lempar jauh bola softball siswa kelas VII SMP Negeri 1 Malang. Kemudian dilakukan uji lanjutan menggunakan teknik leat significance difference (LSD). Dari penghitungan LSD memperoleh hasil $\overline{\mathrm{X}}_{1}$ vs $\overline{\mathrm{X}}_{2}$ besar mean 1,60 > koefisien LSD $\alpha 0,050,0185$, maka dapat disimpulkan bahwa terdapat perbedaan yang signifikan antara pembelajaran metode drill dinamis dengan pembelajaran metode drill statis terhadap peningkatan hasil belajar lempar bola softball.

\section{PEMBAHASAN}

Hasil Analisis Data Tentang Perbedaan Sebelum dan Sesudah Memperoleh Pembelajaran Metode Drill Dinamis terhadap Peningkatan Hasil Belajar Lempar Bola Softball Kelas 7B SMP Negeri 1 Malang 
Hasil analisis data menggunakan Uji t berhubungan untuk mengetahui perbedaan sebelum dan sesudah pembelajaran lempar bola softball menggunakan metode drill dinamis telah diperoleh hasil bahwa thitung 13,640 $>t_{\text {tabel } \alpha 0,05} 2,145$ sehingga hipotesis nihil yang berbunyi tidak ada perbedaan sebelum dan sesudah pembelajaran drill dinamis terhadap peningkatan hasil belajar lempar bola softball peserta didik kelas 7 SMP Negeri 1 Malang ditolak. Hipotesis kerja yang menyatakan bahwa ada perbedaan sebelum dan sesudah pembelajaran metode drill dinamis terhadap peningkatan hasil belajar lempar bola softball peserta didik kelas 7 SMP Negeri 1 Malang diterima. Dengan demikian, pernyataan tersebut dapat diartikan bahwa ada pengaruh sebelum dan sesudah memperoleh pembelajaran metode drill dinamis terhadap peningkatan hasil belajar lempar bola softball peserta didik kelas 7 SMP Negeri 1 Malang.

Ada perbedaan pengaruh sebelum dan sesudah pembelajaran drill dinamis dalam penelitian ini dikarenakan metode drill dinamis adalah metode latihan yang menggunakan banyak variasi. Variasi yang diberikan selama proses pembelajaran diantaranya, variasi jarak, variasi gerakan teknik dasar melempar, dan adanya tambahan gerak awalan pada teknik dasar melempar. Variasi jarak awal yang ditentukan mulai dari 5 meter lalu bertahap hingga 25 meter. Variasi gerakan teknik dasar melempar, pembenaran dasar-dasar melempar yang diawali dengan cara memegang bola, posisi tangan saat akan melempar, posisi badan sebelum melempar hingga gerak lanjutan setelah melakukan lemparan bola. Variasi tambahan gerak awalan pada teknik dasar melempar, berupa jalan beberapa langkah, awalan lari, dan awalan dengan lari serta lompat. Hal tersebut dilakukan dengan bertahap sehingga pembelajaran menggunakan metode drill dinamis memberikan peningkatan hasil belajar lempar jauh yang signifikan.

Ada pengaruh pembelajaran metode drill dinamis dikarena peserta didik mendapatkan pembelajaran dengan menggunakan metode drill dinamis, yang diberikan selama 6 minggu dengan 2 kali pertemuan setiap minggunya. Dalam sekali pertemuan pembelajaran, dilakukan selama 40 menit. Pembelajaran metode drill dinamis dilakukan agar peserta didik tidak bosan dalam mengikuti pembelajaran demi keberhasilan peserta didik dalam menguasai materi. Hal tersebut didukung dengan pendapat Majid (2015:239) bahwa "pembelajaran yang memiliki stimulus bervariasi merupakan bentuk pembelajaran yang dirancang oleh guru dalam konteks proses interaksi belajar mengajar yang ditujukan untuk mengatasi kebosanan peserta didik sehingga dalam situasi belajar mengajar, peserta didik senantiasa menunjukkan ketekunan, serta penuh partisipasi".

Melalui pembelajaran metode drill dinamis peserta didik mendapat kesempatan lebih banyak dan mencoba melakukan porsi tugas yang telah diberikan dalam proses belajar lempar jauh tersebut. Pembelajaran menggunakan metode latihan atau drill ialah suatu teknik yang dapat diartikan sebagai suatu cara mengajar dimana peserta didik melaksanakan kegiatan-kegiatan latihan, agar peserta didik memiliki ketangkasan atau keterampilan yang lebih tinggi dari apa yang telah dipelajari (Roestiyah 2008:125). Peran guru sebagai penyedia materi dan memberikan umpan balik kepada peserta didik dan memastikan peserta didik telah memiliki keterampilan yang diperlukan.

Terkait dengan hasil penelitian terdahulu oleh Fahmi (2018) yang berjudul "Pengaruh Pembelajaran Variasi Dribble Lurus dan Dribble Zig-Zag Menggunakan Modifikasi Bola Plastik Terhadap Peningkatan Hasil Belajar Keterampilan Dribble Sepakbola Siswa Kelas XI SMAN 5 Malang" , yang menyimpulkan bahwa pembelajaran variasi dribble lurus lebih baik dibanding pembelajaran variasi dribble zig-zag untuk meningkatkan hasil belajar keterampilan dribble sepakbola. Dengan dimikian penelitian eksperimen menggunakan metode drill dinamis yang berpengaruh terhadap hasil belajar lempar bola softball telah didukung oleh teori yang relevan dan didukung oleh hasil-hasil penelitian terdahulu.

\section{Pembahasan Hasil Analisis Data Tentang Perbedaan Sebelum dan Sesudah Memperoleh Pembelajaran Metode Drill Statis terhadap Peningkatan Hasil Belajar Lempar Bola Softball Kelas 7B SMP Negeri 1 Malang}

Hasil analisis data menggunakan Uji t berhubungan untuk mengetahui perbedaan sebelum dan sesudah pembelajaran lempar bola softball menggunakan metode drill statis diperoleh hasil bahwa thitung $11,234>t_{\text {tabel }} \alpha 0,052,145$ sehingga hipotesis nihil yang berbunyi tidak ada perbedaan sebelum dan sesudah pembelajaran drill statis terhadap peningkatan hasil belajar lempar bola softball peserta didik kelas 7 SMP Negeri 1 Malang ditolak. Hipotesis yang menyatakan bahwa ada pengaruh sebelum dan sesudah pembelajaran drill stais terhadap peningkatan hasil belajar lempar bola softball peserta didik kelas 7 SMP Negeri 1 Malang diterima. Dengan demikian, pernyataan tersebut dapat diartikan bahwa 
ada pengaruh sebelum dan sesudah memperoleh pembelajaran metode drill statis terhadap peningkatan hasil belajar lempar bola softball peserta didik kelas 7 SMP Negeri 1 Malang.

Ada perbedaan pengaruh sebelum dan sesudah pembelajaran drill statis dikarenakan metode drill statis yang lebih mengutamakan pembenaran pada gerakan-gerakan dasar dari materi lempar bola softball. Pembenaran gerakan-gerakan dasar tersebut diantaranya pembenaran gerak lempar dengan menggunakan media botol, posisi tangan saat memegang bola softball, dan posisi badan saat sebelum melakukan lemparan hingga setelah melakukan lemparan. Pada proses pembelajaran hanya terdapat variasi jarak lempar, yang berawal dari dekat hingga jauh lalu variasi pendek jauh, agar membiasakan peserta didik terhadap gerak dasar melempar yang baik dan benar sehingga pembelajaran metode drill statis dapat memberikan peningkatan hasil belajar lempar bola softball untuk peserta didik kelas 7B SMP Negeri 1 Malang.

Ada perbedaan pengaruh pembelajaran metode drill statis dikarenakan peserta didik telah mendapatkan pembelajaran dengan menggunakan metode drill statis, yang diberikan selama 6 minggu dengan 2 kali pertemuan setiap minggunya. Dalam sekali pertemuan pembelajaran, dilakukan selama 40 menit. Pembenaran gerakan-gerakan dasar dengan metode drill statis akan membentuk kebiasaankebiasaan pada peserta didik untuk melakukan gerakan dasar lempar bola softball yang benar. Sependapat dengan Sagala (2009:217) yang menyatakan bahwa metode latihan (drill) atau metode training merupakan suatu cara mengajar yang baik untuk menanamkan kebiasaan-kebiasaan tertentu. Metode drill merupakan sarana untuk memperoleh suatu ketangkasan, ketepatan, kesempatan, dan keterampilan. Dengan mengulangi gerakan atau kegiatan yang dilakukan, maka seseorang akan dapat membentuk suatu kebiasaan yang akan direkam oleh otak.

Kegiatan yang telah direkam oleh otak akan memudahkan seseorang tersebut dalam melakukannya sehari-hari saat diperlukan. Metode drill statis adalah metode latihan berulang untuk membentuk suatu keterampilan tertentu yang akan direkam oleh otak untuk memudahkan peserta didik dalam melakukan atau mempraktikkannya. Pendapat lain tentang metode drill diberikan oleh Pribadi (2011:84), "metode latihan berulang atau drill and practice berisi serangkaian latihan atau praktik yang sengaja dirancang untuk membangun kecakapan (fluency) dalam sebuah keterampilan baru yang dipelajari oleh peserta didik". Terkait dengan hasil penelitian terdahulu oleh Oktaviani (2018) yang berjudul "Pengaruh Pembelajaran Metode Drill dan Komando Terhadap Peningkatan Hasil Belajar Dribble Bolabasket Siswa Kelas XI SMAN 5 Malang", menyimpulkan bahwa pembelajaran metode drill lebih baik terhadap peningkatan hasil belajar dribble bolabasket siswa kelas XI SMAN 5 Malang dibanding pembelajaran metode komando.

Secara umum dapat dikatakan bahwa dari penelitian ini tentang hasil belajar lempar bola softball menggunakan pembelajaran metode drill statis mempunyai pengaruh untuk meningkatkan hasil belajar lempar bola softball kelas 7B SMP Negeri 1 Malang, hal ini disebabkan proses pembelajaran peserta didik yang mengulang-ulang gerakan yang baik dan benar sehingga gerakan tersebut menjadi kebiasaan baru yang tertanam pada ingatan peserta didik tersebut. Dengan dimikian penelitian eksperimen menggunakan metode drill dinamis yang berpengaruh terhadap hasil belajar lempar bola softball telah didukung oleh teori yang relevan dan didukung oleh hasil-hasil penelitian terdahulu.

\section{Pembahasan Hasil Analisis Data Tentang Perbedaan Pengaruh Pembelajaran Metode Drill Dinamis dan Drill Statis terhadap Peningkatan Hasil Belajar Lempar bola softball Kelas 7B SMP Negeri 1 Malang}

Berdasarkan hasil uji $\mathrm{F}$ ditemukan $\mathrm{F}_{\text {hitung }} 13,0949>\mathrm{F}_{\text {tabel } \alpha 0,05} 4,1708$ serta hasil uji lanjut menggunakan teknik uji LSD (leat significance difference) data sebelum dan sesudah pembelajaran diperoleh hasil $\bar{X}_{1}$ vs $\bar{X}_{2} \quad 1,60>\operatorname{LSD} \alpha 0,050,01$ maka hipotesis nihil yang menyatakan tidak ada pengaruh pembelajaran metode drill dinamis dan drill statis terhadap peningkatan hasil belajar lempar bola softball peserta didik kelas 7 SMP Negeri 1 Malang ditolak, dan hipotesis kerja yang menyatakan ada pengaruh pembelajaran metode drill dinamis dan drill statis terhadap peningkatan hasil belajar lempar bola softball peserta didik kelas 7 SMP Negeri 1 Malang diterima.

Ada peningkatan hasil belajar lempar bola softball karena peserta didik memperoleh pembelajaran metode drill dinamis dan drill statis selama 6 minggu, setiap 1 minggu dilakukan 2 kali pembelajaran yang terbagi pertemuan pertama dilakukan selama 2 × 40 menit dan pertemuan kedua dilakukan selama 1 x 40 menit. Hal tersebut menunjukkan bahwa adanya kegiatan pengulangan. Prinsip hukum latihan adalah koneksi antara kondisi (yang merupakan perangsang) dengan tindakan akan menjadi lebih kuat karena latihan-latihan, tetapi akan melemah bila koneksi antara keduanya tidak dilanjutkan atau dihentikan (Thorndike dalam Rahyubi, 2012:36). Prinsip hukum latihan diatas 
menjelaskan bahwa yang diutamakan dalam belajar adalah pengulangan. Makin sering diulangi, materi pelajaran akan semakin dikuasai.

Di SMP Negeri 1 Malang dalam proses pembelajaran PJOK disajikan materi tentang olahraga softball sedangkan kajian yang dilakukan oleh peneliti adalah pembelajaran lempar bola softball dengan metode drill dinamis dan drill statis. Hal ini berarti pembelajaran lempar bola softball dapat dipandang sebagai pembelajaran yang bermakna, karena hasil pembelajaran dapat digunakan sebagai penilaian keterampilan teknik dasar lempar bola softball yang dibutuhkan dalam permainan dan bermain softball. Kaitannya dengan pembelajaran bermakna Karim (2017) berpendapat pembelajaran bermakna merupukan suatu proses dikaitkan informasi baru pada konsep-konsep releven yang terdapat dalam sturktur kognitif pada inividu.

Peserta didik yang dibimbing untuk terus-menerus melatih kemampuannya sehingga menjadi sutau kebiasaan akan mampu meningkatkan kemampuan dan kreativitasnya. Hal tersebut dapat diperoleh melalui metode pembelajaran drill. Pengalaman belajar melalui aktivitas adalah pengalaman belajar yang diperoleh oleh peserta didik melalui kegiatan pembelajaran yang didesain oleh guru. Keberhasilan peserta didik dalam belajar, tidak ditentukan oleh orang lain termasuk guru, akan tetapi sangat ditentukan oleh kemampuan dan kreativitas peserta didik itu sendiri (Sanjaya dan Budimanjaya, 2017:143).

Pembelajaran dengan metode drill lebih memfokuskan pada latihan secara berulang-ulang sebagai pembiasaan peserta didik terhadap suatu keterampilan. Metode drill ini akan menimbulkan tingkah laku baru apabila peserta didik yang akan belajar telah siap untuk mengikuti pembelajaran dengan metode pembelajaran yang tepat. Yamin (2008:152) menjelaskan bahwa "metode pembelajaran merupakan cara melakukan atau menyajikan, menguraikan, memberi contoh, dan memberi latihan isi pelajaran kepada peserta didik untuk mencapai tujuan tertentu".

Pembelajaran metode drill yang dibedakan menjadi drill dinamis dan drill statis tentunya akan menghasilkan perbedaan dikarenakan perbedaan materi yang disampaikan. Metode drill dinamis menciptakan suasana pembelajaran yang menyenangkan dengan mendapatkan variasi pembelajaran. Belajar akan lebih bersemangat karena peserta didik diberikan kebebasan untuk mengambil keputusan dan kesempatan dalam melakukan tugas secara individu maupun berkelompok. Metode drill dinamis yang bervariasi mampu memberikan berbagai pengalaman kepada peserta didik agar peserta didik mampu mengambil keputusan untuk menggunakan salah satu teknik yang telah dikuasai.

Variasi metode drill dinamis yang diberikan selama proses pembelajaran diantaranya variasi jarak, variasi gerakan teknik dasar melempar, dan adanya tambahan gerakan lanjutan teknik dasar melempar. Peserta didik yang pada awalnya merasa kurang nyaman dengan teknik dasar lempar bola softball akan merasa diuntungkan dengan adanya variasi teknik dasar yang diajarkan. Peserta didik yang telah menemukan teknik dasar yang sesuai untuk dirinya akan merasa jauh lebih percaya diri dan mampu mempraktikkan teknik lempar bola softball dengan benar. Kemampuan tersebut dapat ditumbuhkan dengan cara mengembangkan rasa ingin tahu peserta didik melalui kegiatan mencobacoba, berpikir secara intuitif, atau bereksplorasi (Sanjaya dan Budimanjaya, 2017:150). Variasi pada metode drill dinamis mampu membuat peserta didik berpikir, teknik dasar yang sesuai dengan dirinya. Peserta didik akan mulai mencoba-coba berbagai teknik dasar yang telah diajarkan kemudian akan memutuskan teknik yang dikuasainya.

Metode drill statis merupakan metode drill yang mengutamakan pembenaran gerakan dasar melempar. Dalam pelaksanaan pembelajaran metode drill statis, peserta didik dituntut untuk melakukan gerakan dengan baik dan benar tanpa adanya gerak tambahan seperti yang tertera pada drill dinamis. Metode drill statis membuat peserta didik lebih terpacu untuk menggunakan teknik dasar melempar bola yang diajarkan dengan baik dan benar. Peserta didik terpusat memperbaiki gerak melempar dari cara memegang bola (grip), posisi tangan dan badan sebelum melempar, cara mengayun, posisi melepas bola, hingga gerak lanjutan (followtrough) melempar. Hal tersebut sama seperti pendapat Aprianova \& Hariadi (2016: 71) menyatakan bahwa "latihan yang dilakukan secara kontinyu atau diulang-ulang untuk dapat menambah hasil latihan selalu ada refleksi atau pembenaran kekurangan pada latihan yang telah dilakukan".

Pada penelitian ini telah dihitung seberapa besar peningkatan hasil belajar lempar bola softball

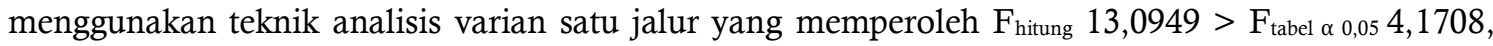
berarti terdapat peningkatan hasil belajar lempar bola softball yang diakibat pembelajaran metode drill dinamis dan drill statis.

Berdasarkan rakpitulasi hasil analisis rata-rata hitung tes lempar bola softball saat tes awal dan tes akhir pada kelompok pembelajaran metode drill dinamis dan drill statis, maka pada kelompok 
pembelajaran metode drill dinamis terdapat peningkatan hasil tes lempar bola softball sebesar $4,70 \mathrm{~m}$, dan pada kelompok pembelajaran metode drill statis terdapat peningkatan hasil tes lempar bola softball sebesar 3,11 m. Berdasarkan data pada tabel analisis di atas, terdapat peningkatan hasil belajar lempar bola softball yang lebih besar pada kelompok pembelajaran menggunakan metode drill dinamis dibanding kelompok pembelajaran menggunakan metode drill statis.

Kaitannya dengan pembelajaran lempar bola softball dengan menggunakan metode drill telah didukung dengan teori tentang hukum latihan Thorndike (Rahyubi, 2012:36) bahwa "semakin sering tingkah laku diulang, dilatih, dan dipraktikkan, maka asosiasi tersebut akan semakin kuat". Artinya bahwa dengan adanya pembelajaran metode drill, perlakuan yang akan diberikan menjadi lebih kuat karena latihan-latihan tetapi akan melemah bila koneksi antara keduanya tidak dilanjutkan atau dihentikan. Dengan demikian berarti pembelajaran lempar bola softball dengan menggunakan metode drill memberikan prinsip yang utama dalam belajar dengan adanya pengulangan.

\section{KESIMPULAN}

Berdasarkan hasil penelitian dapat disimpulkan bahwa terdapat pengaruh pembelajaran metode drill dinamis dan drill statis terhadap peningkatan hasil belajar lempar bola softball kelas 7 SMP Negeri 1 Kota Malang. Hasil analisis data mengacu pada hasil pengujian hipotesis, maka penelitian dapat disimpulkan pertama, ada pengaruh pembelajaran metode drill dinamis terhadap peningkatan hasil belajar lempar jauh bola softball siswa kelas VII SMP Negeri 1 Malang. Kedua, ada pengaruh pembelajaran metode drill statis terhadap peningkatan hasil belajar lempar jauh bola softball siswa kelas VII SMP Negeri 1 Malang. Ketiga, pembelajaran metode drill dinamis lebih baik terhadap peningkatan hasil belajar lempar jauh bola softball siswa kelas VII SMP Negeri 1 Malang, dibandingkan pembelajaran metode drill statis. Besarnya peningkatan hasil belajar lempar jauh bola softball metode drill dinamis sebesar $4,70 \mathrm{~m}$, sedangkan metode koman peningkatan hasil belajar lempar jauh bola softball metode drill statis sebesar $3,11 \mathrm{~m}$.

\section{DAFTAR PUSTAKA}

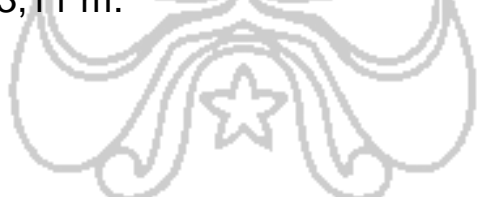

Aprianova dan Hariadi. 2016. Metode drill untuk meningkatkan teknik dasar menggiring bola (dribbling) dalam permainan sepakbola pada siswa sekolah sepakbola putra zodiac kabupaten bojonegoro usia 13-15 tahun. (http://journal.um.ac.id/index.php/jko/article/view/7709), diakses 2 Oktober 2018.

Aunurrahman. 2014. Belajar dan Pembelajaran. Bandung: ALFABETA.

Christina dan Advendi K. 2011. Petunjuk Praktis Bermain Softball. Malang: Wineka Media.

Daryanto, S. K. 2017. Pembelajaran Abad 21. Yogyakarta: Gava Media

Djudin, T. 2013. Statistika Parametrik: Dasar Pemikiran dan Penerapannya dalam Penelitian. Yogyakarta: Tiara Wacana.

Fahmi, M. Y. N. 2018. Pengaruh Pembelajaran Variasi Dribble Lurus dan Dribble Zig-zag Menggunakan Modifikasi Bola Plastik terhadap Peningkatan Hasil Belajar Keterampilan Dribble Sepakbola Siswa Kelas XI SMAN 5 Malang. Skripsi diterbitkan. Malang: FIK UM.

Hamid, M. S. 2014. Metode Edutainment. Jogjakarta: DIVA Press.

Khanifatul. 2013. Pembelajaran Inovatif: Strategi Mengelola Kelas Secara Efektif dan Menyenangkan. Jogjakarta: AR-RUZZ MEDIA.

Kusumawati, M. 2015. Penelitian Pendidikan PENJASORKES (Pendidikan Jasmani Olahraga dan Kesehatan). Bandung: Alfabeta.

Oktaviani. T. S. 2018. Pengaruh Pembelajaran Metode Drill dan Komando terhadap Peningkatan Hasil Belajar Dribble Bolabasket Kelas XI SMAN 5 Malang. Skripsi diterbitkan. Malang: FIK UM.

Rahyubi, H. 2012. Teori-Teori Belajar dan Aplikasi Pembelajaran Motorik. Bandung: Nusa Media

Riyana, C. 2010. Modul 6: Komponen-Komponen Pembelajaran, (Online) , (http://file.upi.edu/Direktori/FIP/JUR._PEND._LUAR_BIASA/196209061986011-

AHMAD_MULYADIPRANA/PDF/Komponen_Pembelajaran.pdf), diakses 2 Oktober 2018.

Sanjaya dan Andi. 2017. Paradigma baru Mengajar. Jakarta: Kencana. 
Sagala, S. 2009. Konsep dan Makna Pembelajaran: Untuk Membantu Memecahkan Problematika Belajar dan mengajar. Bandung: Alfabeta.

Sudaryono dan Asep S. 2012. Statistik Deskriptif: Langkah Mudah Analisis Data. Yogyakarta: Andi Offset.

Wibowo, P. A. 2012. Upaya Meningkatkan Keterampilan Smash Bolavoli Menggunakan Metode Drill Bervariasi untuk Pembelajaran Siswa Kelas Olahraga SMP Negeri 1 Batu. Skripsi diterbitkan. Malang: FIK UM.

Yamin, H. Martinis. 2008. Desain Pembelajaran Berbasis Tingkat Satuan Pendidikan. Jakarta: Gaung Persada Press.

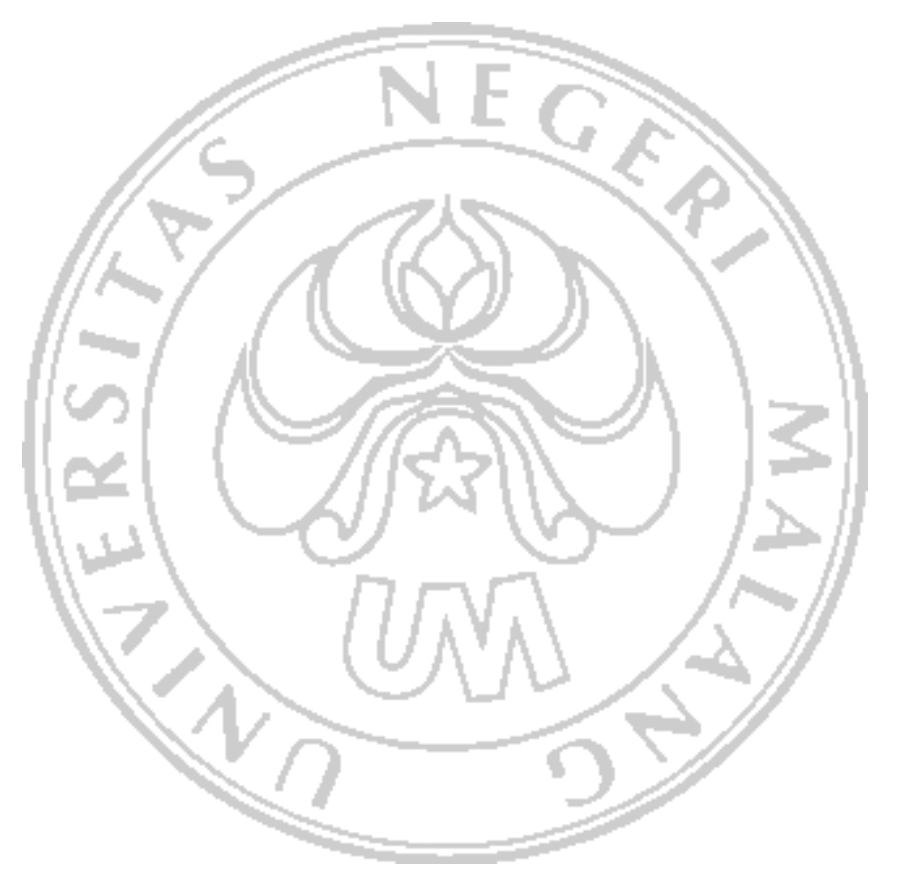

